Article

\title{
Monitoring of Solar Still Desalination System Using the Internet of Things Technique
}

\author{
Mohamed Benghanem ${ }^{1, *}$, Adel Mellit ${ }^{2,3}{ }^{\mathbb{D}}$, Mohammed Emad $^{4}$ and Abdulaziz Aljohani $^{1}(\mathbb{D}$ \\ 1 Physics Department, Faculty of Science, Islamic University, P.O. Box 170, Madinah 42351, Saudi Arabia; \\ A.farhan.j225@gmail.com \\ 2 Renewable Energy Laboratory, Faculty of Sciences and Technology, Jijel University, Ouled-Aissa P.O. Box 98, \\ Jijel 18000, Algeria; adel_mellit@univ-jijel.dz \\ 3 The Abdus Salam International Centre of Theoretical Physics (ICTP), Strada Costiera, 11, 34151 Trieste, Italy \\ 4 Chemistry Department, Faculty of Science, Islamic University, P.O. Box 170, Madinah 42351, Saudi Arabia; \\ mhmd_1428@hotmail.com \\ * Correspondence: mbenghanem@iu.edu.sa
}

Citation: Benghanem, M.; Mellit, A.; Emad, M.; Aljohani, A. Monitoring of Solar Still Desalination System Using the Internet of Things Technique. Energies 2021, 14, 6892. https:// doi.org/10.3390/en14216892

Academic Editor: Manolis Souliotis

Received: 4 September 2021

Accepted: 16 October 2021

Published: 21 October 2021

Publisher's Note: MDPI stays neutral with regard to jurisdictional claims in published maps and institutional affiliations.

Copyright: (c) 2021 by the authors. Licensee MDPI, Basel, Switzerland. This article is an open access article distributed under the terms and conditions of the Creative Commons Attribution (CC BY) license (https:// creativecommons.org/licenses/by/ $4.0 /)$.
Abstract: In this work, a smart solar still prototype for water desalination is designed. It consists of a basic solar still, a solar preheater and a remote monitoring system based on the Internet of Things (IoT) technique. The monitoring system is developed and integrated into the hybrid solar still in order to control its evolution online, as well the quality of the freshwater provided by checking measured parameters such as $\mathrm{pH}$. Thanks to the IoT technique, parameters collected by the monitoring system (e.g., air temperatures, relative humidity, etc.) are uploaded to the cloud for online remote monitoring. The users are notified by an SMS about the status of the system (e.g., water level in the basin, water in the tank, etc.), using an GSM module. The whole system, including the preheater, water pump, valve, sensors and an electronic board, is powered by a photovoltaic module of $75 \mathrm{Wp}$. The results showed that by adding a solar preheater system, the evaporation process is accelerated and, consequently, the daily yield is improved and reaches the value of $12.165 \mathrm{~L} / \mathrm{m}^{2} /$ day. The saline concentration of the tested ground water is $3.9 \mathrm{~g} / \mathrm{Kg}(0.39 \%)$, and, after desalination, the salinity is $0.1 \mathrm{~g} / \mathrm{Kg}(0.01 \%)$.

Keywords: Internet of Things; mobile application; photovoltaic system; remote monitoring; smart water desalination system; solar still

\section{Introduction}

Around the world, there are many regions of vast extent that have numerous favorable features but whose progress is mainly inhibited by a lack of freshwater [1]. This is the case in arid and semi-arid areas, where large-scale (LS) development has already occurred-for example, in parts of the Middle East and North Africa (MENA).

In [2], the authors improved the performance of solar still desalination via the hydrophobic condensation surface using cold plasma technology, and the calculations showed that the produced freshwater using a plasma coating increased by $25.7 \%$ compared to the uncoated system. A novel renewable-energy-based multigenerational system integrated with desalination and molten salt storage subsystems is developed in [3]. Different types of basins have been employed and shown in [4]. The difference between types of basins is due to the nature of the materials used, the geometric form, the type of transparent cover and the means of providing and driving output water. As reported in [5], the outdoor conditions of remote areas allow the best use of solar desalination. By minimizing the heat losses, the daily distilled water increases, which is due to the lower boiling point of saline water inside the solar still under vacuum conditions.

In [6], an experimental system was developed and tested on a new absorber plate. A new active solar still was compared with a conventional system in terms of efficiency and water produced by using a hot water storage tank. In [7], experimental data were 
used to validate the simulated results. The authors studied the effect of different factors on the freshwater productivity and solar still efficiency. Recently, in [8], the authors developed a desalination dual membrane framework that was powered by solar energy for purifying saline water using ancient methods to produce clean water for drinking and irrigation. Moreover, a recent study was conducted using seawater as continuous input into a conventional single-slope solar still [9]. In this work, three kinds of absorbers were tested experimentally. It was found that the results of the absorber with 15 fins were better than those using the flat absorber. Another recent research work was undertaken to enhance a solar still's productivity using thermal process modeling [10]. It was found that the lower mass of water gives the highest daily productivity independently of the incident solar irradiation. In this work, a mathematical model was proposed to predict the performance of solar stills. A new design of a double-slope solar still was elaborated in [11].

In fact, a novel methodology has been established allowing the calculation of the yearly solar thermal energy that can be received by a double-slope still. It was found that this input energy is affected by many parameters, such as the inclination angle of the glass cover, basin length and surface azimuth angle. The results showed that the designed double-slope solar still will receive a yearly solar input energy of $97.67 \mathrm{GJ}$. Another study was conducted to analyze the performance of a tubular solar still with different configurations [12]. Three kinds of solar stills were assessed using a water depth of $1 \mathrm{~cm}$. It was found that the tubular solar still with nano phase change material gave the best performance and highest yield.

The main objective of this work is to design a low-cost smart hybrid solar still water desalination prototype. In fact, there are many configurations of water desalination systems; in this work, we are motivated by the solar still due to its simplicity, ease of implementation and low cost with acceptable efficiency. A monitoring system has been developed for the online control of the desalination unit using IoT technique. The most important parameters controlled by the monitoring system is the quality and the amount of freshwater produced by the system.

This paper is organized as follows: the materials and methods are given in Section 2. The results and discussion are presented in Section 3. The conclusion is presented in the last section, Section 4 .

\section{Materials and Methods}

Figure 1 shows a block diagram of the proposed hybrid solar still system; it consists mainly of:

- A basic solar still that was fabricated with inner dimensions of $1 \mathrm{~m} \times 1 \mathrm{~m}$ (effective area of $1 \mathrm{~m}^{2}$ ) and the glass cover was tilted at $25^{\circ}$ with respect to the horizontal;

- A solar heater for preheating water, which was designed with an area of $1 \mathrm{~m}^{2} \times 10 \mathrm{~cm}$ formed by copper tubes, as shown in the following diagram;

- A monitoring system used for data acquisition and parameter control using the IoT technique;

- A PV system of $75 \mathrm{Wp}$ capacity was used for supplying different components of the system.

Figure 2 shows a photo of the designed hybrid solar heater-solar still prototype.

The main steps of the control process, implemented in the microcontroller, are summarized as follows:

- Initially, the tank (containing salt water) is considered full $(500 \mathrm{~L})$ as well as the basin (100 L);

- The water position in the basin is checked, which should be between two levels $(\mathrm{L} 1=2 \mathrm{~cm}$ and $\mathrm{L} 2=10 \mathrm{~cm}$ ); if the position sensor indicates that the measured level is less than L1, the microcontroller activates the relay and the valve will be opened till the water level L2 is reached; then, the relay is activated automatically by sending a signal from the microcontroller; 
- The water level in the tank is verified; if the level is less than L3 = $500 \mathrm{~L}$, the microcontroller sends a signal to start the water pump, till the L3 is reached;

- $\quad$ The Wi-Fi module is programmed to send the measured parameters to the cloud every 5 min, via the IoT technique [13];

- If the system stops, an anomaly occurs or no distiller water is produced, the user is alerted by a simple SMS via a phone.

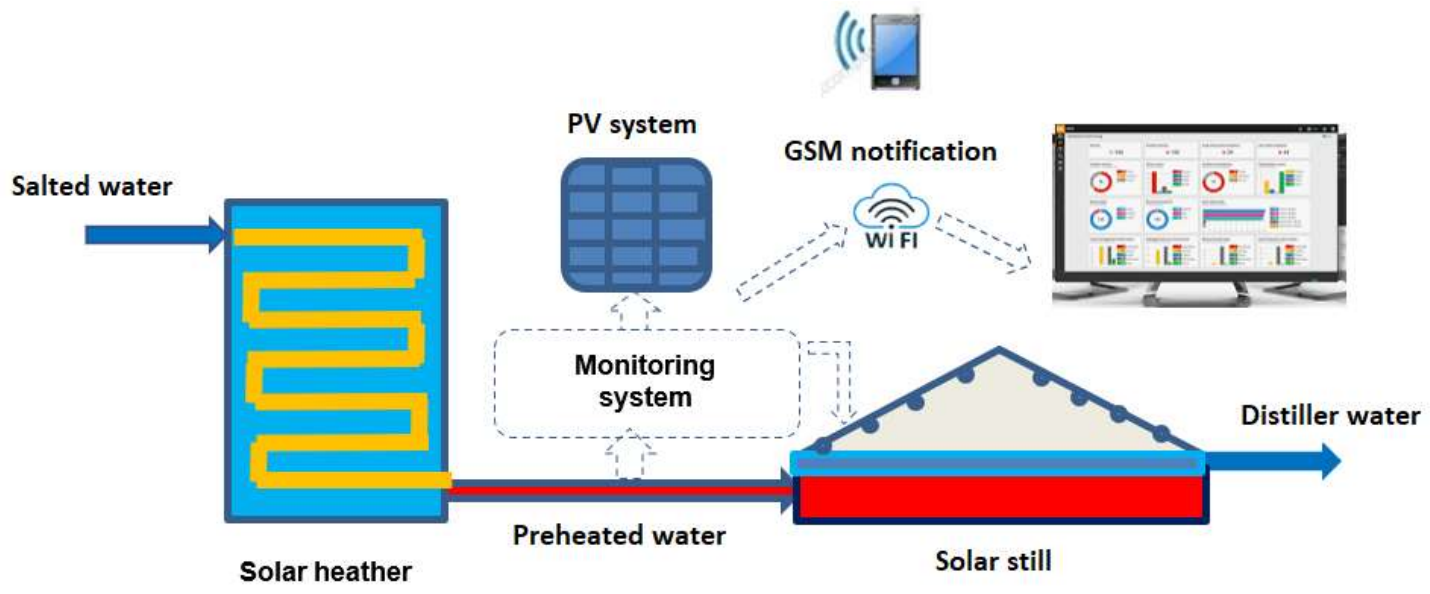

Figure 1. Smart hybrid solar heater-solar still desalination system.

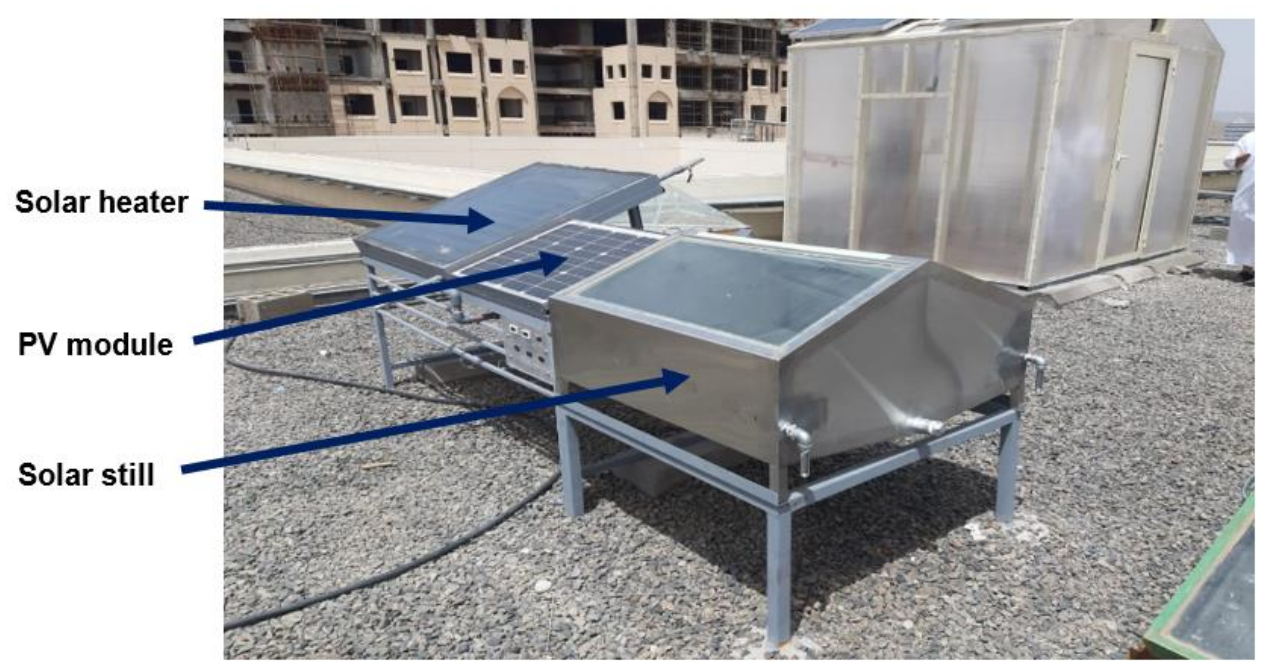

Figure 2. A photo of the designed smart hybrid solar heater-solar still system.

\subsection{Monitoring and Displaying Solar Still Desalination Parameters}

Figure 3 shows the scheme of the developed monitoring system. The different constituents are as follows:

- Sensors (ambient temperature, relative humidity, inside temperature, water temperature, water level and amount of distilled output water);

- $\quad$ Actuators (valve and water pump);

- $\quad$ Liquid crystal display (LCD) permits us to visualize the measured data;

- A low-cost microcontroller (Arduino Mega 2560) is used to control and monitor different parameters inside and outside the solar still desalination unit. The parameters monitored are Ta, Tstill, RH, Tw, WL and Wd (daily amount of output distilled water). 


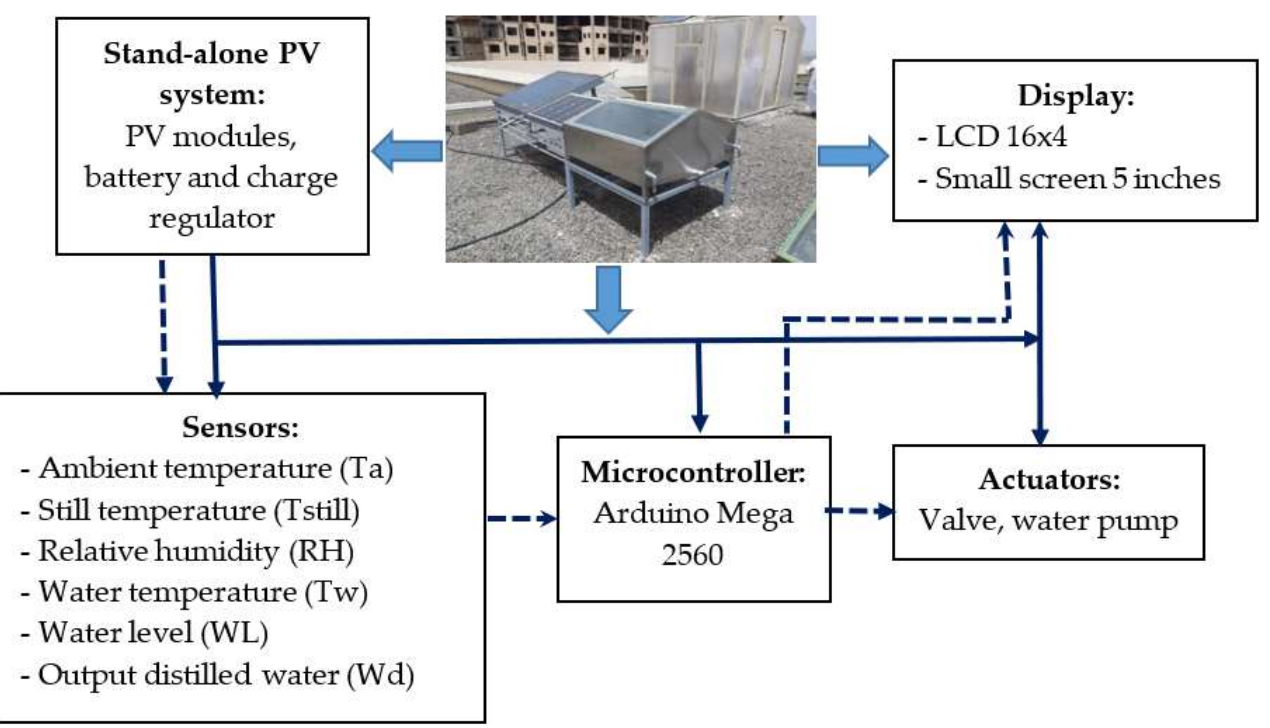

Figure 3. Basic structure of the monitoring system (solid line: power, dashed line: data).

The different steps of the control process are as follows:

- Step \#1: Initialization and loading of reference parameters (Tref, RHref and WLref), which are based on experimental thresholds.

- $\quad$ Step \#2: Measuring real parameters (Ta, Tstill, RH, Tw, WL and Wd).

- Step \#3: Sending signal to the actioners by activating the corresponding relay:

- Water pump: start filling the tank.

- Valve: start filling the solar basin.

\subsection{Webpage Development}

In order to upload and collect measured data and images showing a drop of water on the surface of the still, a Wi-Fi camera (e.g., ESP32) and a Wi-Fi (e.g., NodeMCU) have been used. The webpage was designed for the visualization of the phenomenon of water evaporation. Figure 4 presents a block diagram for uploading the measured data and images onto the webpage using the IoT technique [14].

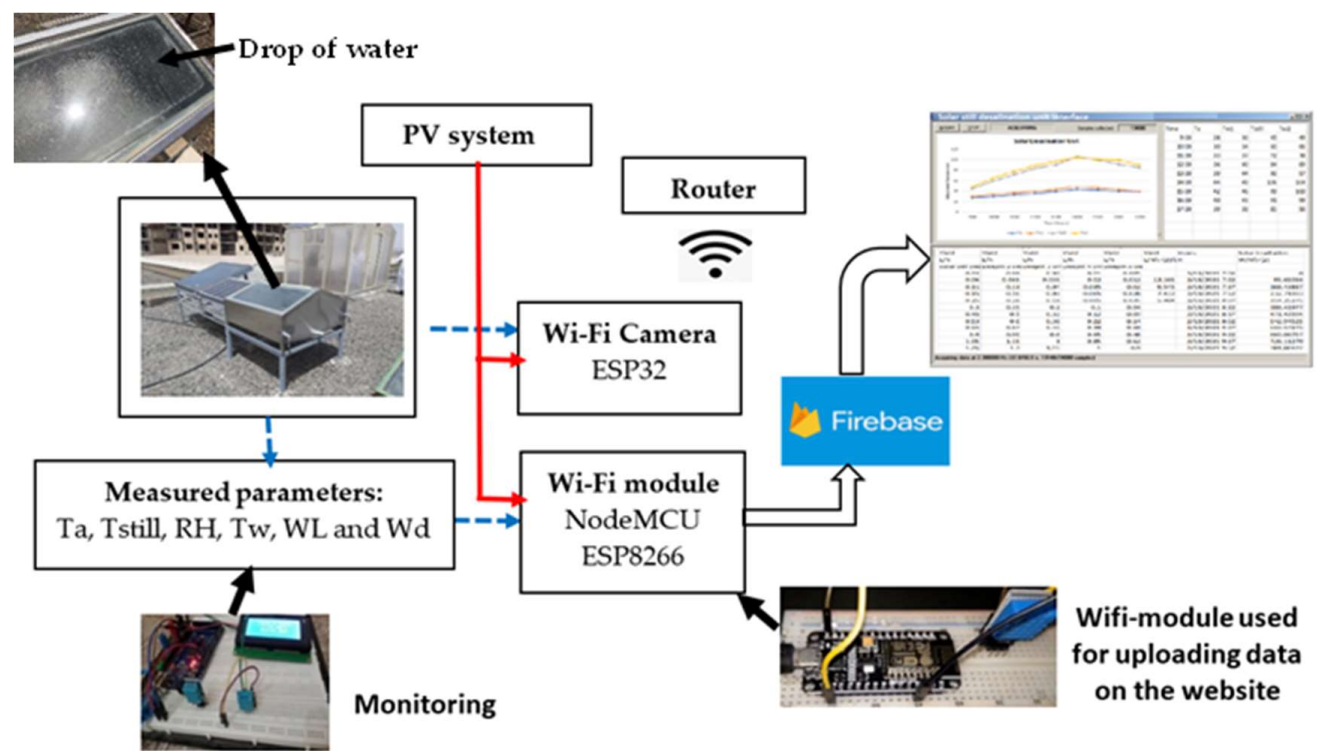

Figure 4. Uploading measured data and images onto the webpage. 
The page configuration has been designed using Hyper Text Markup Language (HTML) and, for an adequate environment, a Cascading Style Sheet (CSS) was used. For creating a dynamic environment, JavaScript was used. The Firebase conceived by Google was used to host the webpage and database management.

\subsection{Mobile Application}

By using the NodeMCU ESP8266 module and Expo React-Native, we developed an application for a mobile phone that allows the visualization of different data issued from solar still desalination unit parameters remotely. The use of a GSM module with Arduino allows notification for users about the status of the solar still desalination unit. Figure 5 provides a block diagram of this application.

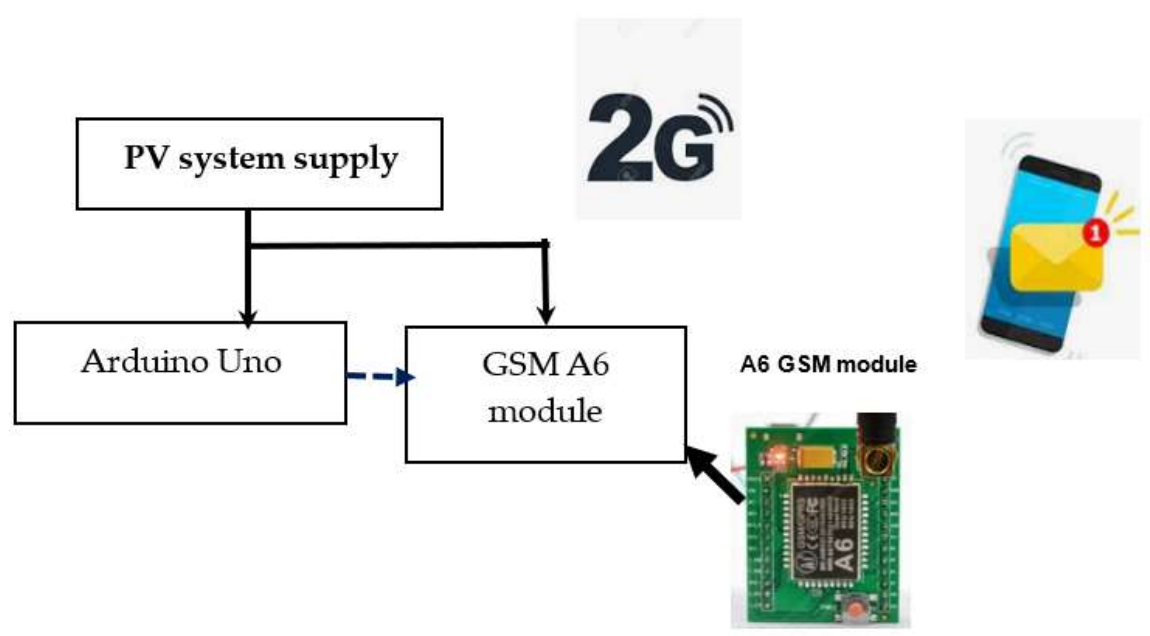

Figure 5. Mobile application structure for SMS notification.

\subsection{Stand-Alone Photovoltaic System}

An autonomous photovoltaic (PV) system has been used to supply the different sensors of the desalination unit, including the water pump and the electronic board. It comprised one PV module ( $75 \mathrm{Wp}$ ) connected to one battery $12 \mathrm{~V} / 200 \mathrm{Ah}$, a solar charge regulator $(12 \mathrm{~V} / 20 \mathrm{~A})$, a voltage regulator and a DC-DC buck converter (in $=7-12 \mathrm{~V}$ and out $=5$ or $3.3 \mathrm{~V})$.

Figure 6 presents the block diagram of the PV system used to supply the electronic board and microcontroller used for monitoring the solar still desalination unit.

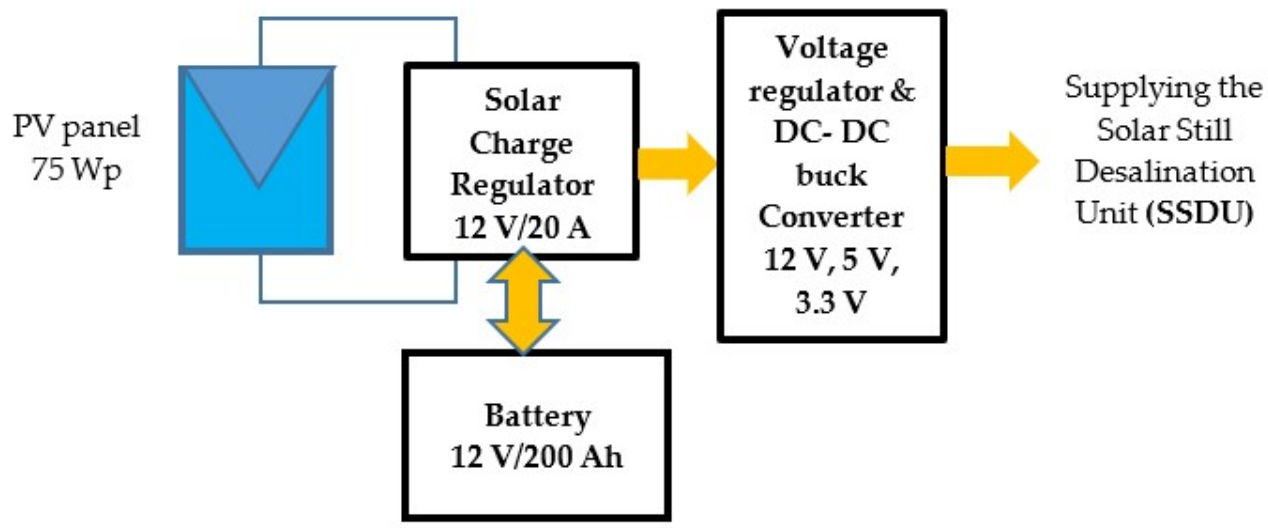

Figure 6. Supplying the SSDU using a PV system. 
Figure 7 shows a photo of the stand-alone PV system installed on the roof of the Faculty of Science at Islamic University (IU) of Madinah, Saudi Arabia.
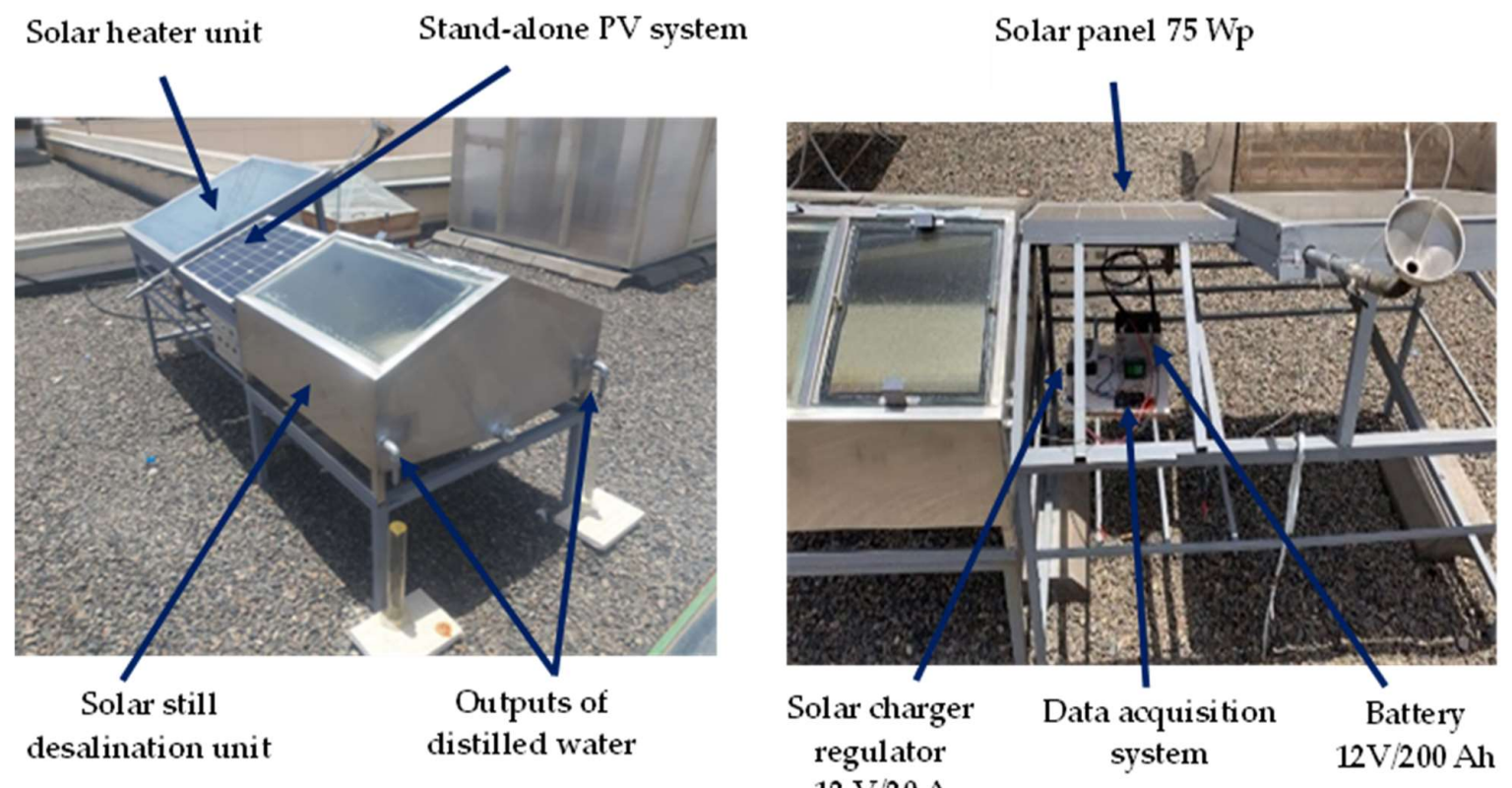

Figure 7. A photo of the solar desalination unit powered by stand-alone PV system (roof of the Faculty of Science building at IU, Madinah, KSA).

\section{Results and Discussion}

To study the performance of the designed solar still desalination prototype, different experiments were performed.

\subsection{Designed Prototype}

Figure 8 shows a photo of the developed solar still desalination prototype, including the microcontroller Arduino Mega Board. The whole prototype's Capital cost (Cs) was around USD 250.

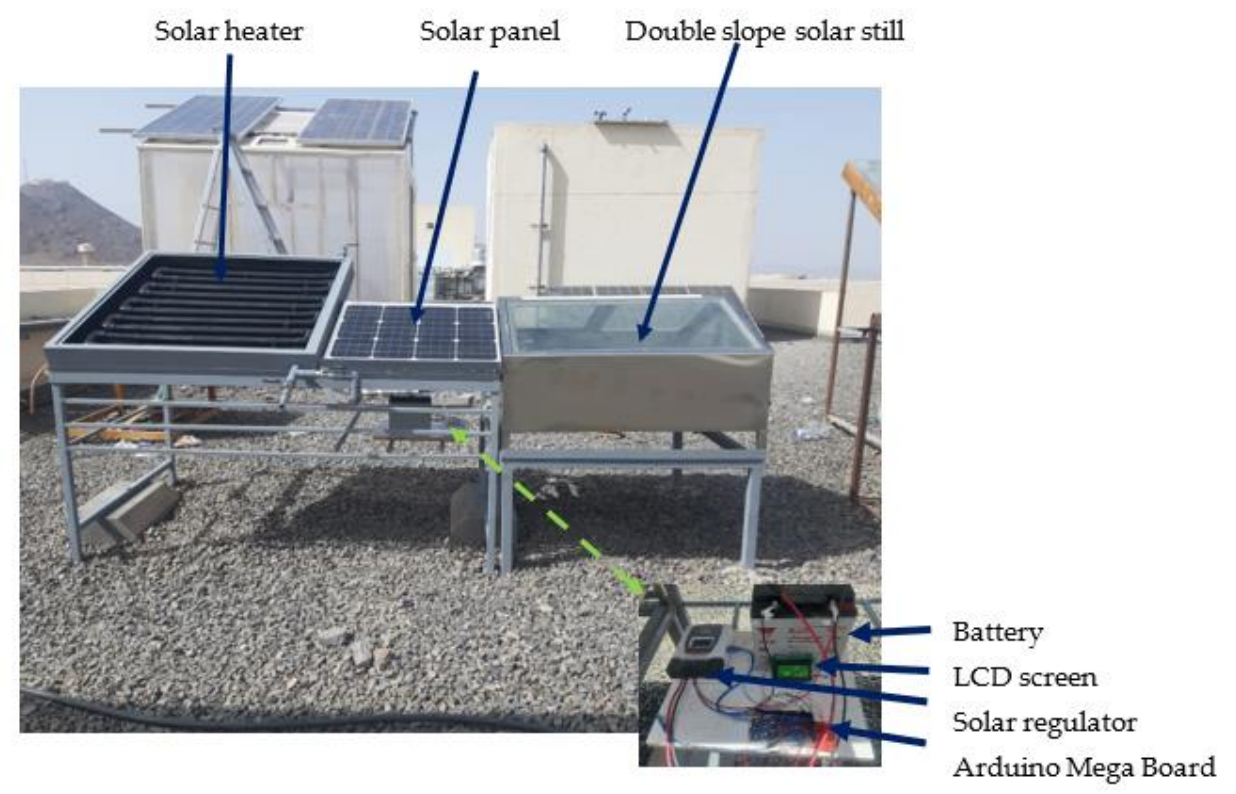

Figure 8. A photo of the smart hybrid solar heater-solar still desalination unit. 


\subsection{Data Visualization Monitoring}

A monitoring system was developed to visualize the measured parameters online. The graphic interface of the main webpage designed for the smart solar desalination unit is presented in Figure 9a. Figure 9b shows the data posted on the webpage, collected from the solar desalination unit. The uploaded data are the real-time values of Ta, Tstill, Tw1 and Tw2 recorded on 18th February 2021.
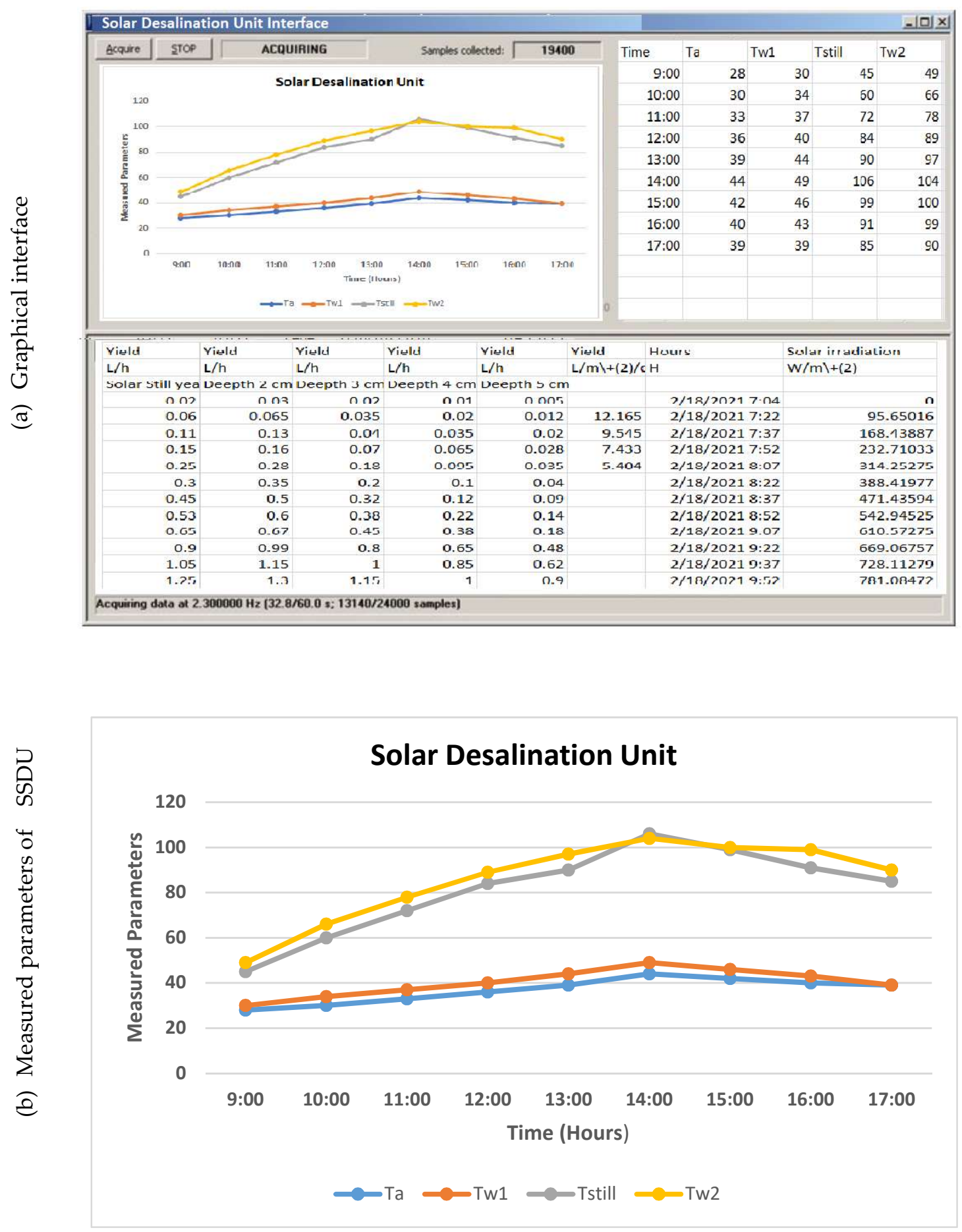

Figure 9. The main webpage of the solar still desalination unit (SSDU). (a) Graphic interface, (b) measured parameters, Ta, Tw1, Tstill and Tw2, on 18 February 2021. 


\subsection{Warning SMS}

A phone application was developed to check the status of the desalination unit. Thus, users can be notified by an SMS if any problem arises. An example of a warning SMS notification informing the user that the tank of salted water is empty is illustrated in Figure 10.

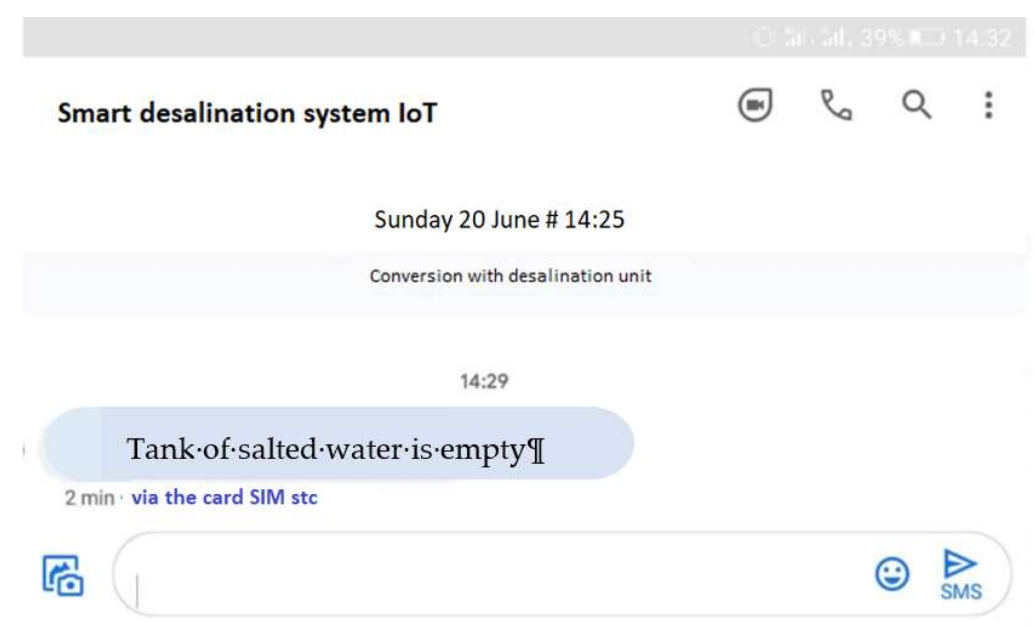

Figure 10. SMS notification (e.g., tank of salted water is empty).

\subsection{Mobile Application}

A photo of the mobile application is presented in Figure 11. This application can help users to control the collected parameters of the desalination unit remotely.

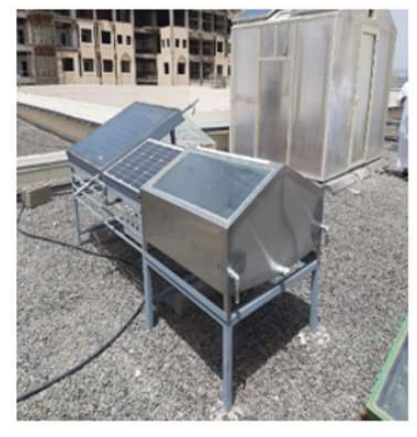

SSDU Prototype

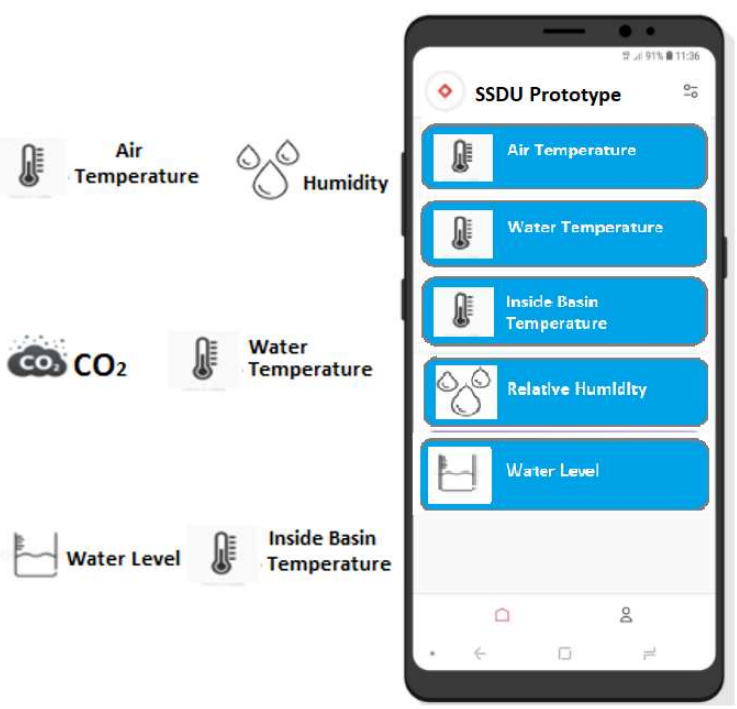

Figure 11. The main Android app screen for the designed smart solar still desalination unit.

\subsection{Effects of Different Parameters on the Yields of Distilled Output Water}

Figure 12a presents the evolution of the hourly output water versus time for different water depths. The maximum yield of distilled water is obtained for a water depth of $2 \mathrm{~cm}$. Figure $12 \mathrm{~b}$ displays the variation in the yield of the solar still for diverse depths. It can be noted from the curve that the maximum yield is obtained at the minimum depth, which is due essentially to the fast evaporation process. The effect of coupling a solar heater on the yield of the solar still was analyzed, as shown in Figure 12c. It can be observed from 
the experimental result that the yield of the hybrid solar heater-solar still is notably better than that of a simple solar still.
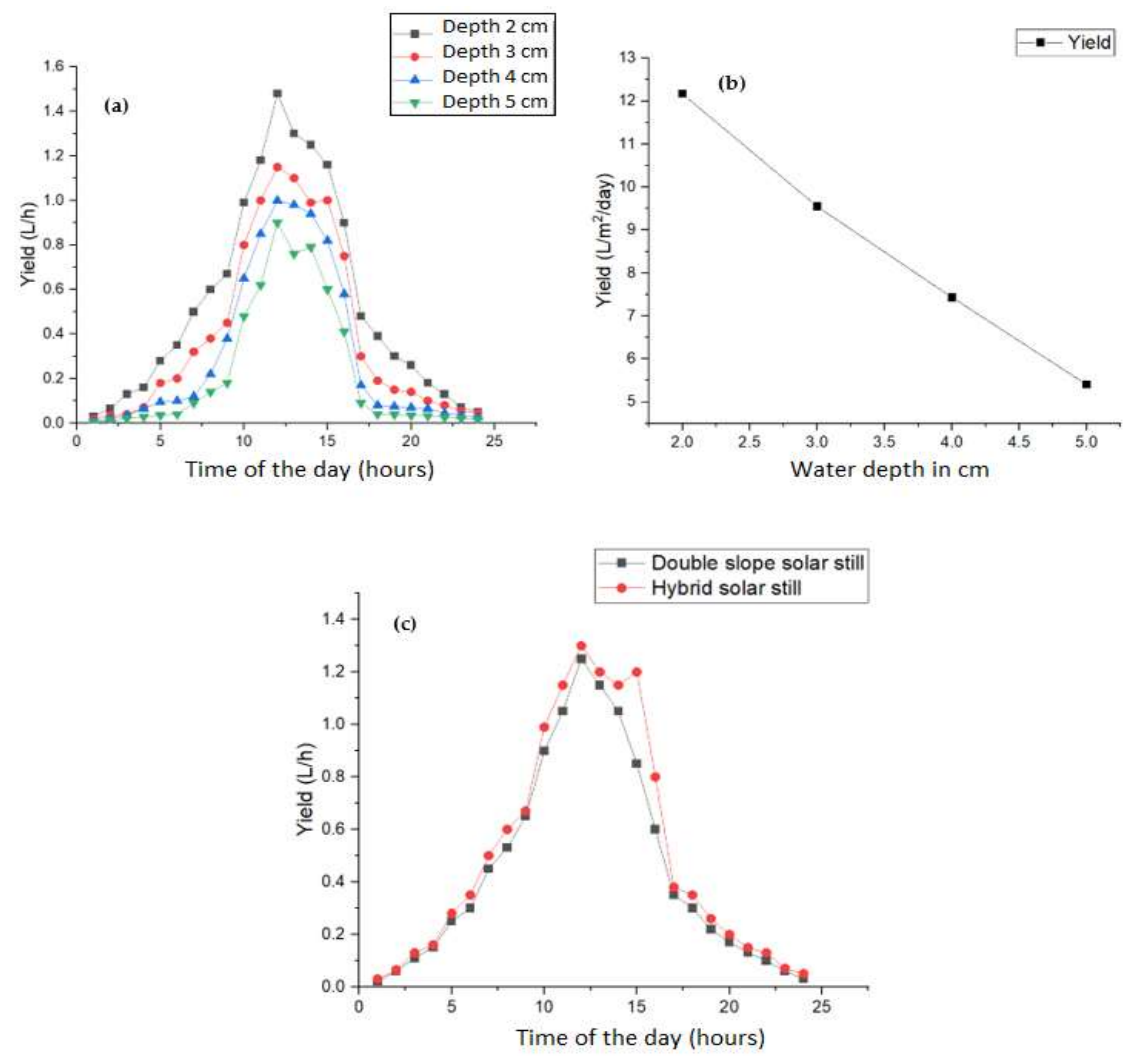

Figure 12. (a) Hourly yield for different water depths, (b) evolution of the yield of still for different water depths and (c) hourly yield of double-slope solar still and proposed hybrid solar still.

It was found that the efficiency of the designed prototype (hybrid solar heater-solar still) is higher than a conventional double-slope solar still for the same basin conditions. The daily yield produced by the double-slope solar still is $9.73 \mathrm{~L} / \mathrm{m}^{2} /$ day, while the hybrid solar heater-solar still produces around $12.165 \mathrm{~L} / \mathrm{m}^{2} /$ day. To check the water quality, some physical-chemical parameters, such as the concentration of hydrogen ions $(\mathrm{pH})$, electrical conductivity (EC), total dissolved solids (TDS) and salt in the groundwater (before and after desalination), are measured. The test results are listed in Table 1.

Table 1. Comparison of groundwater (before and after desalination): physical-chemical parameters.

\begin{tabular}{ccccc}
\hline Chemical Parameters & $\begin{array}{c}\text { Groundwater } \\
\text { before Desalination }\end{array}$ & $\begin{array}{c}\text { Groundwater after } \\
\text { Desalination }\end{array}$ & $\begin{array}{c}\text { Mineral Water } \\
\text { (Nestle) }\end{array}$ & $\begin{array}{c}\text { Ordinary Home } \\
\text { Water }\end{array}$ \\
\hline $\mathrm{pH}$ & 7.68 & $\mathbf{7 . 1 8}$ & 7.15 & 8.13 \\
Electrical conductivity $(\mu \mathrm{S} / \mathrm{cm})$ & 7550 & $\mathbf{3 8 4}$ & 225 & 361 \\
TDS $(\mathrm{mg} / \mathrm{L})$ & 3770 & $\mathbf{2 1 0}$ & 114 & 178 \\
Salt $(\%)$ & 0.39 & $\mathbf{0 . 0 1}$ & 0.01 & 0.01 \\
\hline
\end{tabular}

Bold highlights the results obtained after desalination.

A comparison was made with mineral water (Nestle) and ordinary home drinking water. The results show that the groundwater after desalination has almost the same values of chemical parameters as mineral water (Nestle) and ordinary home drinking water. The water sample analyzed has a $\mathrm{pH}$ within the safe limit of 6.5 to 8.5 standard values [15]. The permissible limit for EC is $300 \mu \mathrm{S} \mathrm{cm}-1$. The EC of the used sample before desalination is $7550 \mu \mathrm{S} / \mathrm{cm}$, which is higher than the standard value, and, after 
desalination, the electrical conductivity is $384 \mu \mathrm{S} / \mathrm{cm}$ [15]. This shows that the EC value of water sample, after desalination, is reduced considerably and is almost close to the ordinary home water at Madinah City. Concerning the TDS, before treatment, the TDS value is $3770(\mathrm{mg} / \mathrm{L})$, and after desalination, it is $210(\mathrm{mg} / \mathrm{L})$. This shows that the TDS value of water after desalination is close to the permissible value, which is $350 \mathrm{mg} / \mathrm{L}[15,16]$. The salinity of the tested groundwater is $0.39 \%$, corresponding to $3.9 \mathrm{~g} / \mathrm{kg}$. After desalination, the salinity is $0.01 \%$, corresponding to $0.1 \mathrm{~g} / \mathrm{kg}$.

\subsection{Cost Calculation of Solar Stills}

The unit cost of the desalination of saline water $(\mathrm{UCdw})$ is the ratio of the total annual cost (TAC) of the passive solar still per unit area and the average annual productivity in liters $\left(\mathrm{M}_{\text {yearly }}\right)$ of the solar still per unit area [17]. The costs of different types of solar stills are given in Table 2.

$$
\mathrm{UCdw}=\frac{\mathrm{TAC}}{\mathrm{M}_{\text {yearly }}}
$$

where TAC depends principally on the present capital cost (Cs), on the number of clear days in a year and on the average daily distillate output per unit area [17].

Table 2. The unit cost of desalination of saline water.

\begin{tabular}{ccccc}
\hline Solar Stills & References & Cs (US\$) & Myearly (L) & UCdw (US\$/L) \\
\hline Double slope & {$[18]$} & 106 & 1511 & 0.007 \\
Hybrid solar heater-double slope & (Present work) & $\mathbf{2 5 0}$ & $\mathbf{1 8 0 0}$ & $\mathbf{0 . 0 2 2}$ \\
Single slope & {$[17]$} & 179 & 1043 & 0.024 \\
Pyramid shape & {$[19]$} & 250 & 1533 & 0.026 \\
Solar still with solar concentrator & {$[20]$} & 300 & 990 & 0.050 \\
\hline
\end{tabular}

Bold highlights the results obtained for the present work.

In Table 2, we show that the double-slope solar still [18] has the lowest cost of desalination (0.007 US\$/L). The proposed hybrid solar heater-solar still presents a cost that is slightly greater than that of the conventional double-slope solar still but a better cost compared to the other types of solar still and gives the best average annual productivity in liters $\left(1800 \mathrm{~L} / \mathrm{m}^{2}\right)$.

\section{Conclusions}

A smart solar still water desalination prototype has been designed and verified experimentally at Madinah City, Saudi Arabia. It has been demonstrated that the proposed hybrid solar heater-solar still water desalination system outperforms the solar still with two slopes. The evaporation process of saline water has been significantly accelerated, consequently improving the daily yield, which reached a maximum value of $12.165 \mathrm{~L} / \mathrm{m}^{2} /$ day, and the quality of distilled water complies with World Health Organization standards.

A low-cost monitoring system has been developed and integrated with the hybrid solar still system. Thanks to the IoT technique, measured data have been posted online for the real-time and remote monitoring of the considered system. The PV system incorporated into the proposed prototype is used to supply the components of the solar still unit, like as sensors, electronic boards and water pump.

Users can monitor and check their system remotely from their offices or homes, if we suppose that such systems are installed in remote areas. The proposed prototype could be generalized for large-scale solar desalination plants.

Author Contributions: Data curation, M.B., A.M. and A.A.; Formal analysis, M.B. and A.M.; Funding acquisition, M.B.; Investigation, M.B. and A.M.; Methodology, M.B., A.M. and M.E.; Supervision, M.B. and A.M.; Writing—original draft, M.B. and A.M. All authors have read and agreed to the published version of the manuscript. 
Funding: This research was funded by the Deputyship for Research \& Innovation, Ministry of Education in Saudi Arabia, Research Project No. 20/1.

Institutional Review Board Statement: Not applicable.

Informed Consent Statement: Not applicable.

Data Availability Statement: Not applicable.

Acknowledgments: The authors extend their appreciation to the Deputyship for Research \& Innovation, Ministry of Education in Saudi Arabia for funding this research work through the project number 20/1.

Conflicts of Interest: The authors declare no conflict of interest.

$\begin{array}{ll}\text { Abbreviations } \\ \text { Cs } & \text { Capital cost } \\ \text { CSS } & \text { Cascading Style Sheets } \\ \text { DC } & \text { Direct current } \\ \text { EC } & \text { Electrical conductivity } \\ \text { GSM } & \text { Global System for Mobile Communications } \\ \text { IoT } & \text { Internet of Things } \\ \text { LED } & \text { Light-emitting diode } \\ \text { LCD } & \text { Liquid crystal display } \\ \text { MENA } & \text { Middle East and North Africa } \\ \text { Myearly } & \text { Average annual productivity of distilled water } \\ \text { NodeMCU } & \text { Node microcontroller unit } \\ \text { pH } & \text { pH is a scale used to specify the acidity or basicity of an aqueous solution } \\ \text { PV } & \text { Photovoltaic } \\ \text { RH } & \text { Relative humidity } \\ \text { RHref } & \text { Reference value of relative humidity } \\ \text { SAPV } & \text { Stand-alone PV system } \\ \text { SMS } & \text { Short Message Service } \\ \text { SSDU } & \text { Solar still desalination unit } \\ \text { Ta } & \text { Air temperature (ambient) } \\ \text { TAC } & \text { Total annual cost } \\ \text { TDS } & \text { Total dissolved solids } \\ \text { Tstill } & \text { Temperature inside the still } \\ \text { Tref } & \text { Reference value of temperature } \\ \text { Tw } & \text { Water temperature } \\ \text { UCdw } & \text { Unit cost of desalination of saline water } \\ \text { WL } & \text { Water level } \\ \text { WLref } & \text { Reference value of water level } \\ \text { Wd } & \text { Distilled water (output water) } \\ \text { Wp } & \text { Watt pick (maximum power of PV panel) } \\ & \end{array}$

\section{References}

1. Kalankesh, R.; Rodríguez-Couto, L.; Zazouli, M.A. Desalination and power generation of Caspian sea by applying new designed microbial desalination cells in batch operation mode. Environ. Prog. Sustain. Energy 2019, 38, 13205. [CrossRef]

2. Khanmohammadi, S.; Khanjani, S. Experimental study to improve the performance of solar still desalination by hydrophobic condensation surface using cold plasma technology. Sustain. Energy Technol. Assess. 2021, 45, 101129. [CrossRef]

3. Ghaffour, N.; Lattemann, S.; Missimer, T.; Ng, K.C.; Sinha, S.; Amy, G. Renewable energy-driven innovative energy-efficient desalination technologies. Appl. Energy 2014, 136, 1155-1165. [CrossRef]

4. Manchanda, H.; Kumar, M. Study of water desalination techniques and a review on active solar distillation methods. Environ. Prog. Sustain. Energy 2018, 37, 444-464. [CrossRef]

5. Hansen, R.S.; Murugavel, K.K. Enhancement of integrated solar still using different new absorber configurations: An experimental approach. Desalination 2017, 422, 59-67. [CrossRef]

6. Naroei, M.; Sarhaddi, F.; Sobhnamayan, F. Efficiency of a photovoltaic thermal stepped solar still: Experimental and numerical analysis. Desalination 2018, 441, 87-95. [CrossRef] 
7. Moungar, H.; Azzi, A.; Sahli, Y.; Hieda, A. Double slope solar still with immersed fins: Theoretical and experimental study. Univ. Politeh. Buchar. Sci. Bull. Ser. C-Electr. Eng. Comput. Sci. 2018, 80, 231-246. [CrossRef]

8. Abed, F.M.; Eleiwi, M.A.; Hasanuzzaman, M.; Islam, M.M.; Mohammed, K.I. Design, development and effects of operational conditions on the performance of concentrated solar collector-based desalination system operating in Iraq. Sustain. Energy Technol. Assess. 2020, 42, 100886. [CrossRef]

9. Mirmanto, I.; Adi Sayoga, M.; Tri Wijayanta, A.; Pulung Sasmito, A.; Muhammad Aziz, M. Enhancement of Continuous-Feed Low-Cost Solar Distiller: Effects of Various Fin Designs. Energies 2021, 14, 4844. [CrossRef]

10. Radomska, E.; Mika, L.; Sztekler, K.; Kalawa, W. Experimental Validation of the Thermal Processes Modeling in a Solar Still. Energies 2021, 14, 2321. [CrossRef]

11. Yousefi, H.; Aramesh, M.; Shabani, B. Design Parameters of a Double-Slope Solar Still: Modelling, Sensitivity Analysis, and Optimization. Energies 2021, 14, 480. [CrossRef]

12. Mohamed Thalib, M.; Muthu Manokar, A.; Essa, F.A.; Vasimalai, N.; Sathyamurthy, R.; Garcia Marquez, F.P. Comparative Study of Tubular Solar Stills with Phase Change Material and Nano-Enhanced Phase Change Material. Energies 2020, 13, 3989. [CrossRef]

13. Wu, F.; Rüdiger, C.; Yuce, M.R. Real-time performance of a self-powered environmental IoT sensor network system. Sensors 2017, 17, 282. [CrossRef] [PubMed]

14. Pattar, S.; Buyya, R.; Venugopal, K.R.; Iyengar, S.S.; Patnaik, L.M. Searching for the IoT resources: Fundamentals, requirements, comprehensive review, and future directions. IEEE Commun. Surv. Tutor. 2018, 20, 2101-2132. [CrossRef]

15. Fondriest Environmental Products. Available online: https://www.fondriest.com/environmentalmeasurements/parameters / water-quality/conductivity-salinity-tds/\#cond8 (accessed on 8 June 2021).

16. What are Total Dissolved Solids (TDS) \& How to Reduce Them? Available online: https://www.kent.co.in/blog/what-are-totaldissolved-solids-tds-how-to-reduce-them/ (accessed on 8 June 2021).

17. Ranjan, K.R.; Kaushik, S.C. Economic feasibility evaluation of solar distillation systems based on the equivalent cost of environmental degradation and high-grade energy savings. Int. J. Low-Carbon Technol. 2016, 11, 8-15. [CrossRef]

18. Al-Hinai, H.; Al-Nassri, M.S.; Jubran, B.A. Effect of climatic, design and operational parameters on the yield of a simple solar still. Energ. Convers. Manag. 2002, 43, 1639-1650. [CrossRef]

19. Fath, H.E.S.; El-Samanoudy, M.; Fahmy, K.; Hassabou, A. Thermal-economic analysis and comparison between pyramid-shaped and single-slope solar still configurations. Desalination 2003, 159, 69-79. [CrossRef]

20. Abdel-Rehim, Z.S.; Lasheen, A. Experimental and theoretical study of a solar desalination system located in Cairo, Egypt. Desalination 2007, 217, 52-64. [CrossRef] 